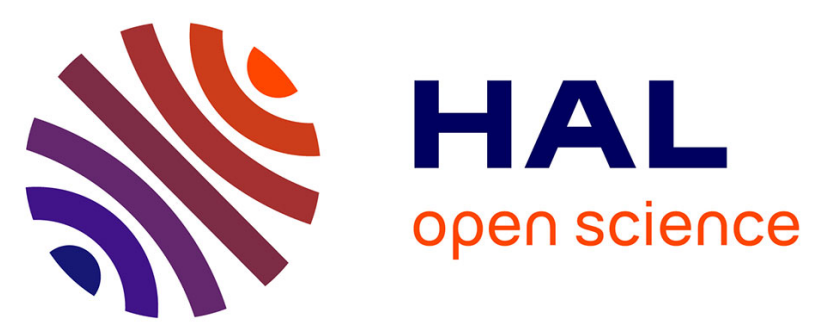

\title{
Activation of nociceptin/orphanin FQ receptors inhibits contextual fear memory reconsolidation
}

Khaoula Rekik, Raquel Faria da Silva, Morgane Colom, Salvatore Pacifico, Nurulain T Zaveri, Girolamo Calo, Claire Rampon, Bernard Frances, Lionel Moulédous

\section{To cite this version:}

Khaoula Rekik, Raquel Faria da Silva, Morgane Colom, Salvatore Pacifico, Nurulain T Zaveri, et al.. Activation of nociceptin/orphanin FQ receptors inhibits contextual fear memory reconsolidation. Neuropharmacology, 2017, 125, pp.39-49. 10.1016/j.neuropharm.2017.07.006 . hal-02384264

\section{HAL Id: hal-02384264 https://hal.science/hal-02384264}

Submitted on 28 Nov 2019

HAL is a multi-disciplinary open access archive for the deposit and dissemination of scientific research documents, whether they are published or not. The documents may come from teaching and research institutions in France or abroad, or from public or private research centers.
L'archive ouverte pluridisciplinaire HAL, est destinée au dépôt et à la diffusion de documents scientifiques de niveau recherche, publiés ou non, émanant des établissements d'enseignement et de recherche français ou étrangers, des laboratoires publics ou privés. 


\section{Title}

Activation of nociceptin/orphanin FQ receptors inhibits contextual fear memory

reconsolidation

\section{Running title}

N/OFQ inhibits fear memory reconsolidation

\section{Authors}

Khaoula REKIK ${ }^{\mathrm{a}}$, Raquel FARIA DA SILVA ${ }^{\mathrm{a}}$, Morgane COLOM ${ }^{\mathrm{a}}$, Salvatore PACIFICO ${ }^{\mathrm{b}}$, Nurulain T. ZAVERI ${ }^{\mathrm{c}}$, Girolamo CALO’d, Claire RAMPON ${ }^{\mathrm{a}}$, Bernard FRANCES ${ }^{\mathrm{a}}$, Lionel

\section{MOULEDOUS ${ }^{\mathrm{a}^{*}}$}

\section{Affiliations}

a Research Center on Animal Cognition, Center for Integrative Biology, Toulouse University,

CNRS, UPS, France

b Department of Chemical and Pharmaceutical Sciences and LTTA, University of Ferrara, 44121 Ferrara, Italy

c Astraea Therapeutic LLC., 320 Logue Avenue, Mountain View, CA 94043, USA

d Department of Medical Sciences, Section of Pharmacology and National Institute of Neuroscience, University of Ferrara, 44121 Ferrara, Italy

* Corresponding author: Lionel Moulédous, Ph.D.

Address:

CRCA/UMR 5169

CNRS/Université Paul Sabatier

118 Route de Narbonne

31062 TOULOUSE Cedex 9

France

Phone: $\quad+33(0) 561556429$

E-mail: $\quad$ lionel.mouledous@univ-tlse3.fr 


\section{ABSTRACT}

Several neuropeptidergic systems act as modulators of cognitive performances. Among them, nociceptin, an opioid-like peptide also known as orphanin FQ (N/OFQ), has recently gained attention. Stimulation of its receptor, the N/OFQ opioid receptor (NOP), which is expressed in brain regions involved in emotion, memory and stress response, has inhibitory effects on the acquisition and/or consolidation of spatial and emotional memory in rodents. Recently, N/OFQ was also proposed to be linked to the pathogenesis of Post-Traumatic Stress Disorder in humans. However, until now the effect of the activation of the N/OFQ-NOP system on already consolidated memory, such as during retrieval and reconsolidation phases, has never been explored. In the present study, we investigated the consequences of systemic injection of NOP agonists or i.c.v. injection of the N/OFQ peptide on the retrieval and the reconsolidation of contextual fear memory in mice. We demonstrate that the activation of the N/OFQ system impairs the reconsolidation of context-dependent but not cue-dependent aversive memories. We also show that this amnestic effect is associated with decreased c-Fos expression in the hippocampus and amygdala. Our data thus provide the first evidence that the NOP receptor could be targeted during the reconsolidation process to weaken maladaptive memories. The N/OFQ-NOP system might constitute in the future an interesting pharmacological target for interfering with so-called "pathological memories", in particular those involving maladaptive contextual memories.

Keywords: nociceptin/orphanin FQ, NOP receptor, contextual fear memory, reconsolidation, hippocampus 


\section{INTRODUCTION}

Long-term memory is a dynamic process. During memory retrieval the memory trace returns to a labile state and has then to be re-stabilized or reconsolidated to ensure long-term storage (Alberini and Ledoux, 2013; Nader, 2015; Nader et al., 2000). Interfering with the reconsolidation process is thus a way to alter the original memory. In humans, inhibiting reconsolidation is a promising strategy to treat disorders that involve maladaptive memories such as post-traumatic stress disorder (PTSD), phobia or addiction (Parsons and Ressler, 2013; Schwabe et al., 2014). Targeting reconsolidation using pharmacological agents, such as adrenergic antagonists, has been successful in attenuating memories in animal models of aversive or appetitive conditioning (Reichelt and Lee, 2013). This approach has also shown promising results in humans suffering from PTSD or phobia. However its effectiveness has also been questioned in some clinical populations (Kroes et al., 2016), highlighting the necessity to better understand the mechanism of memory reconsolidation and to identify new pharmacological targets to attenuate maladaptive memories in humans.

Nociceptin/orphanin FQ (N/OFQ) is a 17-amino acid neuropeptide related to the opioid family (Meunier et al., 1995; Reinscheid et al., 1995). However it does not interact with classical mu, delta and kappa opioid receptors but with another opioid-like G-protein-coupled receptor called ORL1 or NOP (Meunier et al., 2000). Consistent with its widespread distribution in the central nervous system N/OFQ has been shown to modulate many physiological functions in rodents such as pain, feeding, cardiovascular control, reward, stress/anxiety and depression-like behavior (Calo et al., 2000; Lambert, 2008; Zaveri, 2016). In addition, it has been suggested that endogenous N/OFQ could negatively modulate learning and memory processes (Manabe et al., 1998). Supporting this idea, NOP agonists have been shown to interfere with memory acquisition and consolidation in many learning tasks in preclinical animal models (Andero, 2015; Ouagazzal, 2015). More specifically, the injection of 
N/OFQ i.c.v. or of small molecule NOP agonists i.p. inhibits memory acquisition and/or consolidation in spatial, contextual and recognition memory tasks such as the Morris water maze (Higgins et al., 2002; Kuzmin et al., 2009), fear conditioning (Andero et al., 2013; Fornari et al., 2008; Goeldner et al., 2009; Mamiya et al., 2003), passive avoidance (Hiramatsu and Inoue, 1999; Liu et al., 2007; Mamiya et al., 1999) and novel object recognition (Goeldner et al., 2008). N/OFQ was also found to impair learning when injected directly in the dorsal hippocampus (Goeldner et al., 2008; Redrobe et al., 2000; Sandin et al., 1997; Sandin et al., 2004) or the amygdala (Andero et al., 2013; Roozendaal et al., 2007). Moreover, alterations in the endogenous N/OFQ system have been described in mouse and rat models of PTSD (Andero et al., 2013; Zhang et al., 2012; Zhang et al., 2015). Finally, a recent study identified a single-nucleotide polymorphism of the NOP receptor associated with increased PTSD symptoms in individuals exposed to child abuse (Andero et al., 2013). Altogether, these data suggest that the N/OFQ system could be targeted to interfere with maladaptive memories associated with PTSD. However, to further validate this hypothesis, the efficacy of NOP agonists to inhibit memory reconsolidation remains to be determined. While consolidation and reconsolidation processes show many similarities, they also involve specific molecular mechanisms, which take place in distinct brain regions according to different kinetics (Alberini, 2005; Li et al., 2013; von Hertzen and Giese, 2005). Therefore, in the present study we tested whether, similarly to their well-characterized effect on learning and memory consolidation, NOP agonists are able to interfere with the reconsolidation of fear memory. 


\section{MATERIALS AND METHODS}

\subsection{Animals}

A total of 176 C57BL/6 male mice (10-12 week-old, Janvier Labs, Le Genest-Saint-Isle, France) were used. They were housed in collective cages (5 per cage) in a room with controlled temperature $\left(21-23^{\circ} \mathrm{C}\right)$, and a 12-h light/dark cycle $(8.00 \mathrm{am}-8.00 \mathrm{pm})$. Food and water were provided ad libitum. All experiments were carried out in strict accordance with the European guidelines for the care of laboratory animals (European Communities Council Directive 86/609/ECC) and approved by the local ethical committee and the French Ministry of Education and Research (\#1992-2015092911113438). All efforts were made to minimize animal discomfort and to reduce the number of animals used.

\subsection{Drugs}

Ro 65-6570 and N/OFQ were synthesized and purified in house (University of Ferrara) using previously described protocols (Guerrini et al., 1997; Wichmann et al., 1999). AT-403 was synthesized at Astraea Therapeutics. MK-801was purchased from Sigma (St. Quentin Fallavier, France). All small molecules were first prepared as stock solutions in 100\% DMSO then diluted in saline $(0.9 \% \mathrm{NaCl}$, maximal final DMSO concentration was $2 \%)$. For each experiment, vehicle refers to the control saline solution with an equivalent percentage of DMSO. The volume for intra-peritoneal (i.p.) injections was $10 \mathrm{ml} / \mathrm{kg}$. N/OFQ peptide was prepared fresh in saline for intra-cerebro-ventricular (i.c.v.) injections. The volume for i.c.v. injections was $2 \mu 1$.

\subsection{Surgery}


The mice were anaesthetized with chloral hydrate $(400 \mathrm{mg} / \mathrm{kg}$, i.p.) and placed in a stereotactic apparatus (David Kopf Instruments, Tujunga, CA, USA). Guide cannulae were implanted into the lateral ventricle according to the following coordinates: AP $0 \mathrm{~mm}$, Lat \pm 1 $\mathrm{mm}$ from bregma, and DV-2 mm from skull as previously described (Mouledous et al., 2010). After surgery, animals were allowed to recover for 7 to 9 days in their home cage before the start of the behavioral experiments. At the end of the behavioral experiments, all mice were deeply anaesthetized with an overdose of pentobarbital (Ceva Santé Animale, Libourne, France) and their brains removed for histological verification of cannulae placement as previously described (Massaly et al., 2013).

\subsection{Fear conditioning}

Conditioning was done in a rectangular conditioning chamber (length $35 \mathrm{~cm}$, width $20 \mathrm{~cm}$, height $25 \mathrm{~cm}$ ) with a stainless steel rod floor as previously described (Daumas et al., 2004). The experimental device was lit by a $60-\mathrm{W}$ white bulb. Two black-and-white patterns faced the conditioning chamber. The conditioning chamber was cleaned with $70 \%$ aqueous ethanol before each training session. For the consolidation experiment, conditioning consisted in a single session with two trials. After a $120 \mathrm{~s}$ exploration period, the sound $(85 \mathrm{~dB})$ was emitted for $30 \mathrm{~s}$ and a foot shock $(0.7 \mathrm{~mA})$ was superposed during the last $2 \mathrm{~s}$ of the tone. This sequence was repeated twice. Thirty seconds after the last foot shock, the mice were removed from the chamber and returned to their home cage. Twenty-four hours after, the mice were individually tested for freezing to the context in the conditioning chamber for 4 min. Two hours later, they were tested for freezing to the tone in a modified context consisting in a triangular chamber, with white Plexiglas walls and floor. The new chamber was washed with $1 \%$ acetic acid and lit by a $40 \mathrm{~W}$ red bulb. Two minutes after their placement in the modified context, the tone was presented for $2 \mathrm{~min}$. All experiments were videotaped. Freezing, defined 
as the lack of all movement other than respiration and heart-beat, was scored manually in $5 \mathrm{~s}$ bins by an experimenter blind to the treatment groups.

For the contextual fear memory reconsolidation experiments, conditioning was similar except that no sound was emitted. Twenty-four hours after learning, the mice were subjected to a memory retrieval session by exposing them to the conditioning context for $2 \mathrm{~min}$. This retrieval session was immediately followed by drug treatment. Twenty-four hours after memory retrieval, mice were individually checked for freezing to the context in the conditioning chamber for $4 \mathrm{~min}$. Freezing was scored during both the $2 \mathrm{~min}$ retrieval and the 4 min test sessions.

For the tone fear memory reconsolidation experiment, another set-up was used that allowed the use of 3 different contexts. Conditioning was done inside a white chamber in a squared box $(25 \times 25 \mathrm{~cm}$, height $34.5 \mathrm{~cm})$ with a stainless steel rod floor and cleaned with $70 \%$ ethanol between each mouse. It consisted in a single session with two trials as described above. Twenty-four hours after, the recall was performed inside a grey box in a cylinder (diameter $25 \mathrm{~cm}$, height $34.5 \mathrm{~cm}$ ) with a smooth floor and cleaned with $1 \%$ acetic acid between each mouse. The mice were subjected to this memory retrieval session by letting them explore the context for one minute then exposing them to the sound for 30 seconds. This retrieval session was immediately followed by drug treatment. Twenty-four hours after memory retrieval, mice were individually tested for freezing to the sound in a third context, consisting in a triangular box (width $25 \mathrm{~cm}$, length $31 \mathrm{~cm}$, height $34.5 \mathrm{~cm}$ ) with rough floor and black and white striped walls, cleaned with water between each mouse. During this test, the mice were exposed for one minute to the context alone, and then for two minutes to the sound. Freezing was scored automatically using the PolyFear 5.4 tight infrared frame-based software (Imetronic, Pessac, France). 


\subsection{Rotarod}

Rotarod performance was measured using an Ugo Basile rotarod apparatus (Gemonio, Italy, length, $8.5 \mathrm{~cm}$; diameter, $7 \mathrm{~cm}$ ). On day 1 , mice were trained to remain on the rotarod rotating at $12 \mathrm{rpm}$ for $120 \mathrm{~s}$. On day 2, mice were given three trials (12 rpm, up to a maximum of 120 s) $20 \mathrm{~min}$ after agonist treatment and the average score (time before falling from the rod) was used in the final analysis.

\subsection{Elevated plus maze}

The apparatus (Imetronic, Pessac, France) consisted of a plus-shaped track with 2 closed and 2 open arms $(30 \times 10 \times 20 \mathrm{~cm})$ that extended from a central platform $(10 \times 10 \mathrm{~cm})$. The apparatus was elevated $50 \mathrm{~cm}$ above the floor. Each trial began when the mouse was placed in the central zone and lasted $5 \mathrm{~min}$. The number of entries into closed and open arms and the time spent in each arm were monitored automatically based on infrared beam crossing. The maze was cleaned with $70 \%$ ethanol between each mouse to remove olfactory cues.

\subsection{Immunohistochemistry}

c-Fos immunohistochemistry was performed as previously described (Mouledous et al., 2010) with slight modifications. Briefly, mice were overdosed with pentobarbital 90 min after memory retrieval and perfused transcardially with saline followed by $4 \%$ paraformaldehyde (Prolabo, Paris, France). The brains were postfixed overnight at $4^{\circ} \mathrm{C}$ then transferred in $0.1 \mathrm{M}$ phosphate buffer containing $40 \%(\mathrm{w} / \mathrm{v})$ sucrose and $0.1 \%(\mathrm{w} / \mathrm{v})$ sodium azide at $4^{\circ} \mathrm{C} .40 \mu \mathrm{m}$ thick coronal sections were cut in a SM2010 R microtome (Leica biosystems, Nanterre, France) and stored in cryoprotectant at $-20^{\circ} \mathrm{C}$. Sections were incubated with $0.3 \% \mathrm{H}_{2} \mathrm{O}_{2}$ in PBS for $30 \mathrm{~min}$ at room temperature then blocking was performed for $2 \mathrm{~h}$ in PBS containing 0.25\% Triton X-100 and 3\% normal goat serum (Vector Laboratories, Burlingame, CA, 
USA). Sections were then incubated with rabbit anti-c-Fos antibody (Santa Cruz

Biotechnology, Santa Cruz, CA, USA) diluted 1:5 000 in the same buffer for $48 \mathrm{~h}$ at $4^{\circ} \mathrm{C}$. After washing with PBS, sections were incubated with biotinylated goat anti-rabbit antibody (Vector Laboratories) diluted 1:600 in blocking solution for $2 \mathrm{~h}$ at room temperature. Sections were then placed in horseradish peroxidase avidin-biotin complex (Vectastain ABC kit, Vector Laboratories) diluted in PBS $0.5 \%$ Triton X-100 for $1 \mathrm{~h}$ at room temperature. Sections were finally stained in 3,3'-diaminobenzidine substrate kit (Vectastain DAB kit, Vector Laboratories) for 6 min according to manufacturer instructions. Sections were mounted on gelatin-coated slides and counterstained with Nuclear fast red (Vector Laboratories). Sections were viewed under a Leica CTR 600 wide-field microscope (Nanterre, France) and the Mercator software (Explora Nova, La Rochelle, France) was used to delimit the areas of interest (x5 objective) and count c-Fos positive nuclei (40x objective). For each region, 6 sections per animal were analyzed by an experimenter blind to the treatment groups.

\subsection{Statistics}

All results are presented as means \pm SEM. Data were analyzed by Student t-test, one- or twoway ANOVA followed by Bonferroni post hoc as indicated in figure legends, using GraphPad Prism (GraphPad Software, Inc., San Diego, CA, version, 5.01). 


\section{RESULTS}

\subsection{Systemic NOP agonist treatment inhibits contextual fear memory consolidation}

We first verified that, similarly to other NOP agonists, the full agonist Ro 65-6570 (Asth et al., 2016; Wichmann et al., 1999) was able to inhibit contextual fear memory consolidation. Mice were submitted to a fear conditioning protocol consisting in 2 pairings of an auditory CS with a footshock immediately followed by systemic (i.p.) administration of vehicle or Ro 656570 at the dose of 0.1 or $1 \mathrm{mg} / \mathrm{kg}$ (Figure $1 \mathrm{~A}$ ). On the next day, freezing to the conditioning context was evaluated. A one-way ANOVA revealed an effect of drug treatment $\left(\mathrm{F}_{2,27}=3.548\right.$, $\mathrm{p}=0.043)$ and post-hoc tests demonstrated a significant decrease in freezing $(\mathrm{p}<0.05)$ in animals that had received the $1 \mathrm{mg} / \mathrm{kg}$ but not $0.1 \mathrm{mg} / \mathrm{kg}$ dose (Figure 1B). Two hours after contextual memory testing, animals were exposed to the auditory CS in a modified context. The level of freezing to the tone was similar between the 3 groups of mice (One-way ANOVA, $\mathrm{F}_{2,27}=0.094, \mathrm{p}=0.91$ ) (Figure 1C). Based on this last observation we decided to focus our investigations on the reconsolidation of contextual, rather than auditory, fear memory.

\subsection{NOP agonist treatment inhibits contextual fear memory reconsolidation}

Mice were trained to associate the context to the footshocks without auditory CS. The day after training, mice were exposed to the conditioning context for 2 minutes in order to reactivate the memory trace. Drugs were injected immediately after this retrieval session with the aim to interfere with the reconsolidation process. Memory strength was evaluated $24 \mathrm{~h}$ later, by measuring the freezing to the conditioning context (Figure 2A). In addition to Ro 65$6570(1 \mathrm{mg} / \mathrm{kg})$, the NMDA receptor antagonist MK-801 $(0.1 \mathrm{mg} / \mathrm{kg})$ was also tested as a positive control (Charlier and Tirelli, 2011). Both treatments induced a significant decrease in freezing during the retention test whereas there was no difference between groups in the level 
of freezing during the memory retrieval session (Figure 2B). A two-way repeated measures ANOVA revealed a significant interaction between time and drug treatment $\left(\mathrm{F}_{2,21}=3.24\right.$, $\mathrm{p}=0.048)$ and a significant effect of time $\left(\mathrm{F}_{1,21}=45.24, \mathrm{p}<0.001\right)$ but no significant effect of drug treatment $\left(\mathrm{F}_{2,21}=2.908, \mathrm{p}=0,077\right)$. Post-hoc tests demonstrated a significant decrease in freezing in animals treated during the reconsolidation period with MK-801 $(\mathrm{p}<0.05)$ or Ro 65$6570(p<0.01)$ and no difference between MK-801 and Ro 65-6570 treated groups ( $>>0.05)$. Importantly, Ro 65-6570 treatment was ineffective if the retrieval session was omitted (Figure $2 \mathrm{C}$, unpaired t test, $\mathrm{p}=0.933$ ), indicating that memory reconsolidation had to be triggered in order to observe the amnestic effect of the NOP agonist. Since NOP agonists are known to exert anxiolytic effects (Witkin et al., 2014) that could interfere with the expression of freezing behavior, we also looked for a putative residual anxiolytic effect of Ro 65-6570 24h after treatment. Ro 65-6570 treated mice behaved as controls in the elevated plus-maze test (Suppl Figure 1), in agreement with the fact that treatment without memory reactivation does not affect freezing. Next, we conducted another experiment to test a lower dose of $0.1 \mathrm{mg} / \mathrm{kg}$ together with the effective $1 \mathrm{mg} / \mathrm{kg}$ dose (Figure 2D). A one-way ANOVA analysis revealed a significant effect of drug treatment $\left(\mathrm{F}_{2,21}=3.661, \mathrm{p}=0.043\right)$. Post-hoc tests demonstrated a significant decrease in freezing of animals treated with Ro 65-6570 at $1 \mathrm{mg} / \mathrm{kg}(\mathrm{p}<0.05)$ but not at $0.1 \mathrm{mg} / \mathrm{kg}(\mathrm{p}>0.05)$. Higher doses were not tested since preliminary experiments showed that they induced a sedative effect. This effect was evident in the rotarod test for a dose of $3 \mathrm{mg} / \mathrm{kg}$, whereas the $1 \mathrm{mg} / \mathrm{kg}$ dose did not induce motor impairment (Suppl Figure 2). Finally, mice treated with vehicle or $1 \mathrm{mg} / \mathrm{kg}$ Ro 65-6570 were exposed again to the conditioning context 7 days after the first memory test (Figure 2E). The level of freezing remained significantly lower in the Ro 65-6570-treated group (unpaired t-test, $\mathrm{p}=0.045$ ), indicating that the amnestic effect was stable for at least one week. 
In order to further confirm that the NOP receptor can be targeted to inhibit memory reconsolidation, we tested two other highly selective NOP agonists unrelated to Ro 65-6570, using the same procedure as the one described in figure 2A (Figure $3 \mathrm{~A}$ ). In a first experiment we injected the N/OFQ peptide itself in the lateral ventricle immediately after memory retrieval (Figure 3B). A one-way ANOVA revealed an effect of drug treatment $\left(\mathrm{F}_{2,24}=4.65\right.$, $\mathrm{p}=0.019)$ and post-hoc tests demonstrated a significant decrease in freezing $(\mathrm{p}<0.05)$ in animals that had received 3 nmoles of the peptide. Although animals treated with 1 nmole of the peptide showed less freezing than control mice this decrease was not statistically significant $(\mathrm{p}>0.05)$. In a second experiment, we tested i.p. administration of a new highly potent and selective small molecule NOP agonist AT-403 (Figure 3C). AT-403 has high binding affinity for the NOP receptor (Ki $1.13 \mathrm{nM}),>100$-fold selectivity versus the other opioid receptors, and is a full agonist at the NOP receptor (Ferrari et al., 2017). A one-way ANOVA revealed an effect of drug treatment $\left(\mathrm{F}_{2,22}=4.846, \mathrm{p}=0.018\right)$ and post-hoc tests demonstrated a significant decrease in freezing $(\mathrm{p}<0.05)$ in animals that had received the 0.1 $\mathrm{mg} / \mathrm{kg}$ dose as well as a significant difference between the $0.1 \mathrm{mg} / \mathrm{kg}$ and $0.03 \mathrm{mg} / \mathrm{kg}$ groups $(p<0.05)$ but not between the $0.03 \mathrm{mg} / \mathrm{kg}$ and vehicle groups $(\mathrm{p}>0.05)$. Altogether these results demonstrate that activating central NOP receptors during memory reconsolidation interferes with this process, thus resulting in a significant decrease in contextual fear memory retention.

\subsection{NOP agonist treatment does not interfere with contextual fear memory retrieval}

The memory impairments that we observed thus far following Ro65-6570 administration cannot be attributed to a drug effect on memory acquisition or retrieval since it was injected after learning (consolidation experiment) or after memory recall (reconsolidation experiment). In the next experiment we asked whether NOP agonist administration could interfere with 
memory retrieval by injecting Ro 65-6570 20 min before, instead of immediately after, animal re-exposure to the conditioning context (Figure 4A). Memory strength was also evaluated 24h later, by measuring the freezing to the conditioning context. Freezing levels during the retrieval session were similar between NOP agonist and vehicle-injected mice (Figure 4B). When tested for memory retention $24 \mathrm{~h}$ later, Ro 65-6570-treated mice showed a lower level of freezing compared to control mice. However, unlike for the post-retrieval injection experiment, a two-way repeated measures ANOVA revealed a significant effect of time $\left(\mathrm{F}_{1,18}=15.24, \mathrm{p}<0.01\right)$ but no significant interaction between time and drug treatment $\left(\mathrm{F}_{1,18}=0.763, \mathrm{p}=0.394\right)$, and only a trend for a significant effect of treatment $\left(\mathrm{F}_{1,18}=4.357\right.$, $\mathrm{p}=0.051)$. Overall these data suggest that Ro 65-6570 injection prior to re-exposure to the conditioning context does not affect memory retrieval. Moreover, we could not demonstrate a significant inhibitory effect on memory reconsolidation under these administration conditions.

\subsection{NOP agonist treatment following memory retrieval inhibits c-Fos expression in the}

\section{hippocampus and the amygdala}

The NOP receptor is widely distributed in the central nervous system (Mollereau and Mouledous, 2000) and therefore the application of NOP agonist in our experiments could interfere with neuronal processes in different brain regions involved in contextual fear memory. To address this issue we investigated the effect of post-retrieval Ro 65-6570 administration in the two main brain areas associated with contextual and emotional memory, namely the hippocampus and the amygdala respectively (Baldi and Bucherelli, 2015; Izquierdo et al., 2016). Conditioning and drug administration procedures were similar to those in the reconsolidation experiment (Figure 2A) except that animals were sacrificed $90 \mathrm{~min}$ after memory retrieval. Expression of the immediate early gene c-Fos was detected by immunohistochemistry as a molecular correlate of neuronal plasticity. In the dorsal 
hippocampus, Ro 65-6570 administration resulted in a significant decrease in the density of cFos positive cells in the CA3 $(37.3 \%, \mathrm{p}=0.034)$ and CA1 $(61.9 \%, \mathrm{p}=0.041)$ regions but not in the dentate gyrus (DG, $\mathrm{p}=0.25)$ (Figure 5A). In the ventral hippocampus, NOP agonist treatment significantly reduced densities of c-Fos cells in CA1 $(48.2 \%, \mathrm{p}=0.029)$ but not in CA3 ( $p=0.202)$ nor in the DG $(p=0.668)$ (Figure 5B). In the amygdala, Ro 65-6570-induced decrease in the density of c-Fos positive cells was significant in the central region (CeA, $54.5 \%, \mathrm{p}=0.016)$ whereas in the basolateral part (BLA) the $47.5 \%$ decrease did not reach statistical significance $(\mathrm{p}=0.056)$ (Figure 5B). Our data show that impaired contextual memory reconsolidation triggered by NOP receptor activation is associated with a reduction in c-Fos expression in brain regions that support fear memory formation and storage.

\subsection{NOP agonist treatment does not inhibit cue-dependent fear memory reconsolidation}

Ro 65-6570 treatment reduces c-Fos expression not only in the hippocampus but also in the amygdala. This suggests that NOP agonists might also be able to interfere with amygdaladependent hippocampus-independent memory reconsolidation. To test this hypothesis, mice were trained to associate an auditory CS to the footshocks in a first context. The next day, mice were exposed to the CS in another context in order to reactivate the memory trace. Drugs were injected immediately after this retrieval session. Memory strength was evaluated 24h later, by measuring freezing to the CS in a third context (Figure 6A). Both during retrieval and test sessions, the level of freezing was similar between mice treated with vehicle, Ro 65-6570 (1 mg/kg) or AT-403 (0.1 mg/kg) (Figure 6B). A two-way repeated measures ANOVA revealed no significant interaction between time and drug treatment $\left(\mathrm{F}_{2,22}=1.322\right.$, $\mathrm{p}=0.287)$ and no significant effect of time $\left(\mathrm{F}_{1,22}=1.612, \mathrm{p}=0.217\right)$ or drug treatment $\left(\mathrm{F}_{2,22}=\right.$ $1.344, \mathrm{p}=0.281)$. Therefore, similarly to their effect on memory consolidation, the NOP 
agonists tested in this study inhibit selectively the reconsolidation of context- but not cuedependent fear memory.

\section{DISCUSSION}

Previous studies have shown that NOP agonists negatively regulate memory acquisition and consolidation in rodents (Abdel-Mouttalib 2015, Andero 2015). More specifically, i.c.v. injection of N/OFQ peptide (Mamiya et al., 2003) or i.p. administration of small molecule NOP agonists (Andero et al., 2013; Goeldner et al., 2009) inhibit fear memory acquisition and/or consolidation in mice. Our results validate and extend these findings using another small molecule agonist, Ro 65-6570 (Wichmann et al., 1999), closely related to the Ro 646198 compound used by Goeldner et al. (Goeldner et al., 2009). These two agonists were effective in inhibiting contextual fear memory consolidation at equivalent systemic doses. The same doses were inactive on tone fear conditioning thus confirming previous evidence that NOP receptor activation was more efficient in interfering with contextual than cued fear memory (Fornari et al., 2008; Goeldner et al., 2009; Mamiya et al., 2003). Overall the fact that Ro 65-6570 induced amnesia for the conditioning context when injected immediately after the acquisition session confirms that systemic treatment with NOP agonists can inhibit the consolidation phase of contextual memory. Previous studies have also shown that treatment with NOP agonists does not affect the retrieval of hippocampus-dependent memories (Fornari et al., 2008; Goeldner et al., 2009; Goeldner et al., 2008). Again, we confirm these previous findings in this study by showing that systemic administration of Ro 65-6570 before re-exposing the animals to the conditioning context does not modify the expression of the conditioned freezing behavior. 
Our demonstration that NOP agonist treatment inhibits fear memory consolidation together with previous converging evidence (Andero et al., 2013) suggest that the N/OFQ system could be targeted to attenuate traumatic memory, for example in PTSD patients. However, in order to validate this hypothesis, it was necessary to study the effect of NOP agonists on the memory reconsolidation process for two main reasons. First, in many cases, therapeutic interventions occur at a time point when traumatic memory has already been consolidated, and therefore it is the reconsolidation phase that is targeted by the treatment (Parsons and Ressler, 2013; Schwabe et al., 2014). Second, the consolidation and reconsolidation processes show many similarities but also involve distinct molecular mechanisms (Alberini, 2005). For example, BDNF down-regulation in the hippocampus (Lee et al., 2004), or blocking of histamine $\mathrm{H}_{3}$ or muscarinic receptors in the BLA (Bucherelli et al., 2006), inhibit fear memory consolidation but not reconsolidation. Therefore, the main goal of the present study was to test whether NOP agonists were able to interfere with aversive memory reconsolidation.

After confirming that NOP agonists were more effective in modulating contextual than cued fear memory, we decided to focus initially on the reconsolidation of contextual fear memory. We first validated the fact that our memory reactivation procedure ( 2 min re-exposure to the context) was indeed sufficient to destabilize the memory trace. To do so, we used the noncompetitive NMDA receptor antagonist MK-801 which was shown to disrupt contextual fear memory reconsolidation after systemic or intra-hippocampal administration (Charlier and Tirelli, 2011; Lee and Hynds, 2013). Indeed treatment with MK-801 immediately after memory retrieval resulted in a decrease in memory retention when tested $24 \mathrm{~h}$ later. The main observation of the present study is that the NOP receptor agonist Ro 65-6570 produced the same amnestic effect. The memory retrieval session was mandatory for Ro 65-6570 to reduce freezing to the context and this decrease in freezing could not be attributed to any residual 
anxiolytic effect. We can therefore conclude that Ro 65-6570 acted by inhibiting the memory reconsolidation process. This decrease in memory retention was also observed when animals were treated immediately after memory retrieval by either i.c.v. N/OFQ or i.p. AT-403. The N/OFQ peptide being an endogenous ligand of the NOP receptor displays very high selectivity (Toll et al., 2016). Similarly the recently discovered small molecule agonist AT403 is one of the best NOP agonists in terms of potency and selectivity (Ferrari et al., 2017). The similar effects of three chemically unrelated NOP-selective ligands thus confirm that the NOP receptor is indeed mediating the inhibition of contextual memory reconsolidation observed in this study. The effect was achieved with intermediate doses of Ro 65-6570 compared to its lower anxiolytic (Asth et al., 2016) and higher sedative doses (present rotarod results; (Rizzi et al., 2016)). Importantly, doses of Ro 65-6570 and AT-403 that were efficient in inhibiting contextual memory reconsolidation had no effect on tone fear memory when the drugs were injected immediately after cue-induced memory reactivation. This suggests that hippocampus-dependent contextual memory traces are more prone to destabilization by NOP agonists than amygdala-dependent simple associations.

Providing further insights onto the potential cellular mechanisms supporting the effect of Ro 65-6570 on fear memory reconsolidation, we found that post-retrieval administration of this drug reduced c-Fos expression in CA1 and CA3 regions of the dorsal hippocampus. These sub-regions are known to be associated with the reactivation and reconsolidation of contextual fear memory (Besnard et al., 2014; Hall et al., 2001; Inaba et al., 2015; Mamiya et al., 2009). Interestingly, it was recently demonstrated that the inhibition of dorsal CA1 pyramidal cells following contextual fear memory retrieval was sufficient to impair memory reconsolidation (Lux et al., 2017). Ro 65-6570 could therefore exert a direct inhibitory effect on the plasticity of pyramidal hippocampal neurons which express NOP receptors (Mollereau and Mouledous, 2000; Ozawa et al., 2015). The observed reduction in c-Fos positive neurons could be related 
to a pre- and/or post-synaptic inhibition of NMDA-dependent plasticity (Bongsebandhuphubhakdi and Manabe, 2007; Goeldner et al., 2009; Goeldner et al., 2008; Mamiya et al., 2003; Manabe et al., 1998). Post-retrieval Ro 65-6570 administration also significantly reduced c-Fos expression in the CA1 region of the ventral hippocampus as well as in the central part of the amygdala, two regions that are activated following fear memory retrieval (Besnard et al., 2014; Chia and Otto, 2013; Hall et al., 2001; Mamiya et al., 2009). At the cellular level, the inhibitory effect of the NOP agonist is therefore not restricted to the contextual part of the fear memory circuitry but also concerns its emotional part (Izquierdo et al., 2016). However it is worth noting that the inhibition was not significant in the BLA which is the major region for CS-US association in the fear conditioning paradigm. This is consistent with the notion that systemic NOP agonist administration is more efficient in interfering with fear memory associated with a context (disruption of hippocampal plasticity) than with discrete cues (less efficient disruption of amygdalar plasticity) (Fornari et al., 2008; Goeldner et al., 2009; Mamiya et al., 2003). However, NOP receptors are present in the amygdala and, similarly to the hippocampus, Ro 65-6570 could produce its effect in this region by interfering directly with glutamate signaling (Kallupi et al., 2014). Finally, inhibitory NOP receptors expressed in almost all aminergic and cholinergic nuclei (Mollereau and Mouledous, 2000) could also exert an indirect modulatory influence on fear memory processing (Izquierdo et al., 2016). Altogether, post-retrieval Ro 65-6570 silencing effects are consistent with the anatomical and functional distribution of NOP receptors and nicely support our behavioral data. The strong inhibition observed in the dorsal hippocampus also suggests that NOP agonists could be efficient in interfering with the reconsolidation of other types of contextdependent memories such as drug-induced place preference (Reichelt and Lee, 2013).

Targeting reconsolidation using pharmacological agents is a promising approach to treat pathological memories in humans. Our data suggest that NOP agonists could be used to 
disrupt some types of maladaptive memories. However more preclinical studies are needed to fully validate their usefulness. The magnitude of the effect NOP agonists on contextual fear memory was similar to that of the NMDA receptor antagonist MK-801. It was also equivalent to the efficacy of the $\beta$-adrenergic receptor antagonist propranolol reported in the literature (Abrari et al., 2008; Muravieva and Alberini, 2010). However, contextual fear memory was not fully erased and we could not demonstrate a significant effect when Ro 65-6570 was injected before memory retrieval. Further studies are therefore warranted to improve treatment efficacy, for example using agonists with a longer duration of action or performing additional reactivation sessions. It would also be informative to assess the effect of NOP ligands on stronger and older memories and to study the duration of the amnestic effect at later time points. Finally, a possible limitation of the usefulness of NOP agonists in the clinic comes from the observation of their lack of effect on auditory cue-dependent fear memory reconsolidation. However, it is worth mentioning that fear conditioning in rodents does not recapitulate all aspects of pathological traumatic memories in humans. Therefore, it is difficult to predict drugs' efficacy in patients simply based on their effect or a lack of effect in preclinical models of aversive memory. For example, propranolol treatment led to promising results in humans suffering from PTSD or phobia (Kroes et al., 2016) although its effect on tone fear memory reconsolidation in mouse has been challenged (Vetere et al., 2013). Additional experiments using animal models with better predictive validity are therefore needed (Borghans and Homberg, 2015; Bowers and Ressler, 2015).

In conclusion, this study provides the first demonstration that NOP receptors can be targeted to prevent memory reconsolidation. In that sense, it might open new avenues to improve the treatment of pathological forms of memories, in particular those associated with impaired context processing (Careaga et al., 2016; Liberzon and Abelson, 2016). 
Supplementary information is available at the Neuropharmacology website.

\section{FUNDING AND DISCLOSURE}

K.R. was supported by Laboratoires Phodé. This work was supported by funds from CNRS (to B.F and L.M.), University Paul Sabatier Toulouse (to B.F. and L.M.), University of Ferrara (FAR 2015 grant to G.C.), and the Italian Ministry of Research (PRIN 2015WX8Y5B grant to G.C.). The authors declare no competing financial interests in relation to the work described.

\section{ACKNOWLEDGEMENTS}

We thank Pr Pascal Roullet for helpful discussions and Dr Sébastien Lopez for technical advice. We also thank the ABC facility and ANEXPLO Toulouse for housing mice. 


\section{REFERENCES}

Abrari, K., Rashidy-Pour, A., Semnanian, S., Fathollahi, Y., 2008. Administration of corticosterone after memory reactivation disrupts subsequent retrieval of a contextual conditioned fear memory: dependence upon training intensity. Neurobiol Learn Mem 89, 178184.

Alberini, C. M., 2005. Mechanisms of memory stabilization: are consolidation and reconsolidation similar or distinct processes? Trends Neurosci 28, 51-56.

Alberini, C. M., Ledoux, J. E., 2013. Memory reconsolidation. Curr Biol 23, R746-750. Andero, R., 2015. Nociceptin and the nociceptin receptor in learning and memory. Prog Neuropsychopharmacol Biol Psychiatry 62, 45-50.

Andero, R., Brothers, S. P., Jovanovic, T., Chen, Y. T., Salah-Uddin, H., Cameron, M., Bannister, T. D., Almli, L., Stevens, J. S., Bradley, B., Binder, E. B., Wahlestedt, C., Ressler, K. J., 2013. Amygdala-dependent fear is regulated by Oprl1 in mice and humans with PTSD. Sci Transl Med 5, 188ra173.

Asth, L., Ruzza, C., Malfacini, D., Medeiros, I., Guerrini, R., Zaveri, N. T., Gavioli, E. C., Calo, G., 2016. Beta-arrestin 2 rather than $\mathrm{G}$ protein efficacy determines the anxiolytic-versus antidepressant-like effects of nociceptin/orphanin FQ receptor ligands. Neuropharmacology $105,434-442$.

Baldi, E., Bucherelli, C., 2015. Brain sites involved in fear memory reconsolidation and extinction of rodents. Neurosci Biobehav Rev 53, 160-190.

Besnard, A., Laroche, S., Caboche, J., 2014. Comparative dynamics of MAPK/ERK signalling components and immediate early genes in the hippocampus and amygdala following contextual fear conditioning and retrieval. Brain Struct Funct 219, 415-430. 
Bongsebandhu-phubhakdi, S., Manabe, T., 2007. The neuropeptide nociceptin is a synaptically released endogenous inhibitor of hippocampal long-term potentiation. J Neurosci $27,4850-4858$.

Borghans, B., Homberg, J. R., 2015. Animal models for posttraumatic stress disorder: An overview of what is used in research. World J Psychiatry 5, 387-396.

Bowers, M. E., Ressler, K. J., 2015. An Overview of Translationally Informed Treatments for Posttraumatic Stress Disorder: Animal Models of Pavlovian Fear Conditioning to Human Clinical Trials. Biol Psychiatry 78, E15-27.

Bucherelli, C., Baldi, E., Mariottini, C., Passani, M. B., Blandina, P., 2006. Aversive memory reactivation engages in the amygdala only some neurotransmitters involved in consolidation. Learn Mem 13, 426-430.

Calo, G., Guerrini, R., Rizzi, A., Salvadori, S., Regoli, D., 2000. Pharmacology of nociceptin and its receptor: a novel therapeutic target. Br J Pharmacol 129, 1261-1283.

Careaga, M. B., Girardi, C. E., Suchecki, D., 2016. Understanding posttraumatic stress disorder through fear conditioning, extinction and reconsolidation. Neurosci Biobehav Rev $71,48-57$.

Charlier, Y., Tirelli, E., 2011. Differential effects of histamine H(3) receptor inverse agonist thioperamide, given alone or in combination with the N-methyl-d-aspartate receptor antagonist dizocilpine, on reconsolidation and consolidation of a contextual fear memory in mice. Neuroscience 193, 132-142.

Chia, C., Otto, T., 2013. Hippocampal Arc (Arg3.1) expression is induced by memory recall and required for memory reconsolidation in trace fear conditioning. Neurobiol Learn Mem $106,48-55$.

Daumas, S., Halley, H., Lassalle, J. M., 2004. Disruption of hippocampal CA3 network: effects on episodic-like memory processing in C57BL/6J mice. Eur J Neurosci 20, 597-600. 
Ferrari, F., Malfacini, D., Journigan, B. V., Bird, M. F., Guerrini, R., Lambert, D. G., Calo, G., Zaveri, N. T., 2017. In vitro pharmacological characterization of a novel unbiased NOP receptor-selective nonpeptide agonist AT-403. Pharmacol Res Perspect.

Fornari, R. V., Soares, J. C., Ferreira, T. L., Moreira, K. M., Oliveira, M. G., 2008. Effects of nociceptin/orphanin FQ in the acquisition of contextual and tone fear conditioning in rats. Behav Neurosci 122, 98-106.

Goeldner, C., Reiss, D., Wichmann, J., Kieffer, B. L., Ouagazzal, A. M., 2009. Activation of nociceptin opioid peptide (NOP) receptor impairs contextual fear learning in mice through glutamatergic mechanisms. Neurobiol Learn Mem 91, 393-401.

Goeldner, C., Reiss, D., Wichmann, J., Meziane, H., Kieffer, B. L., Ouagazzal, A. M., 2008. Nociceptin receptor impairs recognition memory via interaction with NMDA receptordependent mitogen-activated protein kinase/extracellular signal-regulated kinase signaling in the hippocampus. J Neurosci 28, 2190-2198.

Guerrini, R., Calo, G., Rizzi, A., Bianchi, C., Lazarus, L. H., Salvadori, S., Temussi, P. A., Regoli, D., 1997. Address and message sequences for the nociceptin receptor: a structureactivity study of nociceptin-(1-13)-peptide amide. J Med Chem 40, 1789-1793.

Hall, J., Thomas, K. L., Everitt, B. J., 2001. Cellular imaging of zif268 expression in the hippocampus and amygdala during contextual and cued fear memory retrieval: selective activation of hippocampal CA1 neurons during the recall of contextual memories. J Neurosci 21, 2186-2193.

Higgins, G. A., Kew, J. N., Richards, J. G., Takeshima, H., Jenck, F., Adam, G., Wichmann, J., Kemp, J. A., Grottick, A. J., 2002. A combined pharmacological and genetic approach to investigate the role of orphanin FQ in learning and memory. Eur J Neurosci 15, 911-922. Hiramatsu, M., Inoue, K., 1999. Effects of nocistatin on nociceptin-induced impairment of learning and memory in mice. Eur J Pharmacol 367, 151-155. 
Inaba, H., Tsukagoshi, A., Kida, S., 2015. PARP-1 activity is required for the reconsolidation and extinction of contextual fear memory. Mol Brain 8, 63 .

Izquierdo, I., Furini, C. R., Myskiw, J. C., 2016. Fear Memory. Physiol Rev 96, 695-750.

Kallupi, M., Varodayan, F. P., Oleata, C. S., Correia, D., Luu, G., Roberto, M., 2014.

Nociceptin/orphanin FQ decreases glutamate transmission and blocks ethanol-induced effects in the central amygdala of naive and ethanol-dependent rats. Neuropsychopharmacology 39, 1081-1092.

Kroes, M. C., Schiller, D., LeDoux, J. E., Phelps, E. A., 2016. Translational Approaches Targeting Reconsolidation. Curr Top Behav Neurosci 28, 197-230.

Kuzmin, A., Madjid, N., Johansson, B., Terenius, L., Ogren, S. O., 2009. The nociceptin system and hippocampal cognition in mice: a pharmacological and genetic analysis. Brain Res 1305 Suppl, S7-19.

Lambert, D. G., 2008. The nociceptin/orphanin FQ receptor: a target with broad therapeutic potential. Nat Rev Drug Discov 7, 694-710.

Lee, J. L., Everitt, B. J., Thomas, K. L., 2004. Independent cellular processes for hippocampal memory consolidation and reconsolidation. Science 304, 839-843.

Lee, J. L., Hynds, R. E., 2013. Divergent cellular pathways of hippocampal memory consolidation and reconsolidation. Hippocampus 23, 233-244.

Li, Y., Meloni, E. G., Carlezon, W. A., Jr., Milad, M. R., Pitman, R. K., Nader, K., Bolshakov, V. Y., 2013. Learning and reconsolidation implicate different synaptic mechanisms. Proc Natl Acad Sci U S A 110, 4798-4803.

Liberzon, I., Abelson, J. L., 2016. Context Processing and the Neurobiology of PostTraumatic Stress Disorder. Neuron 92, 14-30. 
Liu, E. H., Lee, T. L., Nishiuchi, Y., Kimura, T., Tachibana, S., 2007. Nocistatin and its derivatives antagonize the impairment of short-term acquisition induced by nociceptin. Neurosci Lett 416, 155-159.

Lux, V., Masseck, O. A., Herlitze, S., Sauvage, M. M., 2017. Optogenetic Destabilization of the Memory Trace in CA1: Insights into Reconsolidation and Retrieval Processes. Cereb Cortex 27, 841-851.

Mamiya, N., Fukushima, H., Suzuki, A., Matsuyama, Z., Homma, S., Frankland, P. W., Kida, S., 2009. Brain region-specific gene expression activation required for reconsolidation and extinction of contextual fear memory. J Neurosci 29, 402-413.

Mamiya, T., Noda, Y., Nishi, M., Takeshima, H., Nabeshima, T., 1999. Nociceptin system plays a role in the memory retention: involvement of naloxone benzoylhydrazone binding sites. Neuroreport 10, 1171-1175.

Mamiya, T., Yamada, K., Miyamoto, Y., Konig, N., Watanabe, Y., Noda, Y., Nabeshima, T., 2003. Neuronal mechanism of nociceptin-induced modulation of learning and memory: involvement of N-methyl-D-aspartate receptors. Mol Psychiatry 8, 752-765.

Manabe, T., Noda, Y., Mamiya, T., Katagiri, H., Houtani, T., Nishi, M., Noda, T., Takahashi, T., Sugimoto, T., Nabeshima, T., Takeshima, H., 1998. Facilitation of long-term potentiation and memory in mice lacking nociceptin receptors. Nature 394, 577-581.

Massaly, N., Dahan, L., Baudonnat, M., Hovnanian, C., Rekik, K., Solinas, M., David, V., Pech, S., Zajac, J. M., Roullet, P., Mouledous, L., Frances, B., 2013. Involvement of protein degradation by the ubiquitin proteasome system in opiate addictive behaviors.

Neuropsychopharmacology 38, 596-604.

Meunier, J., Mouledous, L., Topham, C. M., 2000. The nociceptin (ORL1) receptor: molecular cloning and functional architecture. Peptides 21, 893-900. 
Meunier, J. C., Mollereau, C., Toll, L., Suaudeau, C., Moisand, C., Alvinerie, P., Butour, J. L., Guillemot, J. C., Ferrara, P., Monsarrat, B., et al., 1995. Isolation and structure of the endogenous agonist of opioid receptor- like ORL1 receptor Nature 377, 532-535.

Mollereau, C., Mouledous, L., 2000. Tissue distribution of the opioid receptor-like (ORL1) receptor. Peptides 21, 907-917.

Mouledous, L., Frances, B., Zajac, J. M., 2010. Modulation of basal and morphine-induced neuronal activity by a NPFF(2) selective agonist measured by c-Fos mapping of the mouse brain. Synapse 64, 672-681.

Muravieva, E. V., Alberini, C. M., 2010. Limited efficacy of propranolol on the reconsolidation of fear memories. Learn Mem 17, 306-313.

Nader, K., 2015. Reconsolidation and the Dynamic Nature of Memory. Cold Spring Harb Perspect Biol 7.

Nader, K., Schafe, G. E., Le Doux, J. E., 2000. Fear memories require protein synthesis in the amygdala for reconsolidation after retrieval. Nature 406, 722-726.

Ouagazzal, A. M., 2015. Nociceptin/Orphanin-FQ Modulation of Learning and Memory. Vitam Horm 97, 323-345.

Ozawa, A., Brunori, G., Mercatelli, D., Wu, J., Cippitelli, A., Zou, B., Xie, X. S., Williams, M., Zaveri, N. T., Low, S., Scherrer, G., Kieffer, B. L., Toll, L., 2015. Knock-In Mice with NOP-eGFP Receptors Identify Receptor Cellular and Regional Localization. J Neurosci 35, 11682-11693.

Parsons, R. G., Ressler, K. J., 2013. Implications of memory modulation for post-traumatic stress and fear disorders. Nat Neurosci 16, 146-153.

Redrobe, J. P., Calo, G., Guerrini, R., Regoli, D., Quirion, R., 2000. [Nphe(1)]-Nociceptin (113)-NH(2), a nociceptin receptor antagonist, reverses nociceptin-induced spatial memory impairments in the Morris water maze task in rats. Br J Pharmacol 131, 1379-1384. 
Reichelt, A. C., Lee, J. L., 2013. Memory reconsolidation in aversive and appetitive settings. Front Behav Neurosci 7, 118.

Reinscheid, R. K., Nothacker, H. P., Bourson, A., Ardati, A., Henningsen, R. A., Bunzow, J. R., Grandy, D. K., Langen, H., Monsma, F. J., Jr., Civelli, O., 1995. Orphanin FQ: a neuropeptide that activates an opioidlike G protein- coupled receptor. Science 270, 792-794. Rizzi, A., Cerlesi, M. C., Ruzza, C., Malfacini, D., Ferrari, F., Bianco, S., Costa, T., Guerrini, R., Trapella, C., Calo, G., 2016. Pharmacological characterization of cebranopadol a novel analgesic acting as mixed nociceptin/orphanin FQ and opioid receptor agonist. Pharmacology Research \& Perspectives 4, e00247.

Roozendaal, B., Lengvilas, R., McGaugh, J. L., Civelli, O., Reinscheid, R. K., 2007.

Orphanin FQ/nociceptin interacts with the basolateral amygdala noradrenergic system in memory consolidation. Learn Mem 14, 29-35.

Sandin, J., Georgieva, J., Schott, P. A., Ogren, S. O., Terenius, L., 1997. Nociceptin/orphanin FQ microinjected into hippocampus impairs spatial learning in rats. Eur J Neurosci 9, 194197.

Sandin, J., Ogren, S. O., Terenius, L., 2004. Nociceptin/orphanin FQ modulates spatial learning via ORL-1 receptors in the dorsal hippocampus of the rat. Brain Res 997, 222-233. Schwabe, L., Nader, K., Pruessner, J. C., 2014. Reconsolidation of Human Memory: Brain Mechanisms and Clinical Relevance. Biol Psychiatry 76, 274-280.

Toll, L., Bruchas, M. R., Calo, G., Cox, B. M., Zaveri, N. T., 2016. Nociceptin/Orphanin FQ Receptor Structure, Signaling, Ligands, Functions, and Interactions with Opioid Systems. Pharmacol Rev 68, 419-457.

Vetere, G., Piserchia, V., Borreca, A., Novembre, G., Aceti, M., Ammassari-Teule, M., 2013. Reactivating fear memory under propranolol resets pre-trauma levels of dendritic spines in basolateral amygdala but not dorsal hippocampus neurons. Front Behav Neurosci 7, 211. 
von Hertzen, L. S., Giese, K. P., 2005. Memory reconsolidation engages only a subset of immediate-early genes induced during consolidation. J Neurosci 25, 1935-1942.

Wichmann, J., Adam, G., Rover, S., Cesura, A. M., Dautzenberg, F. M., Jenck, F., 1999. 8acenaphthen-1-yl-1-phenyl-1,3,8-triaza-spiro[4.5]decan-4-one derivatives as orphanin FQ receptor agonists. Bioorg Med Chem Lett 9, 2343-2348.

Witkin, J. M., Statnick, M. A., Rorick-Kehn, L. M., Pintar, J. E., Ansonoff, M., Chen, Y., Tucker, R. C., Ciccocioppo, R., 2014. The biology of Nociceptin/Orphanin FQ (N/OFQ) related to obesity, stress, anxiety, mood, and drug dependence. Pharmacol Ther 141, 283-299. Zaveri, N. T., 2016. Nociceptin Opioid Receptor (NOP) as a Therapeutic Target: Progress in Translation from Preclinical Research to Clinical Utility. J Med Chem 59, 7011-7028. Zhang, Y., Gandhi, P. R., Standifer, K. M., 2012. Increased nociceptive sensitivity and nociceptin/orphanin FQ levels in a rat model of PTSD. Mol Pain 8, 76.

Zhang, Y., Simpson-Durand, C. D., Standifer, K. M., 2015. Nociceptin/orphanin FQ peptide receptor antagonist JTC-801 reverses pain and anxiety symptoms in a rat model of posttraumatic stress disorder. Br J Pharmacol 172, 571-582. 


\section{FIGURE LEGENDS}

Figure 1. Post-training treatment with Ro 65-6570 inhibits contextual fear memory consolidation. (A) Schematic representation of the procedure. FC, fear conditioning; Ro65, Ro 65-6570. (B) The percentage of time spent freezing during exposure to the conditioning context is significantly reduced in mice treated with $1 \mathrm{mg} / \mathrm{kg}$ of NOP agonist immediately after conditioning. (C) Freezing to the tone is not affected. Vehicle (n=12), Ro 65-6570 0.1 $\mathrm{mg} / \mathrm{kg}(\mathrm{n}=10)$, and Ro 65-6570 $1 \mathrm{mg} / \mathrm{kg}(\mathrm{n}=8)$. Bars represent mean \pm SEM. *, $\mathrm{p}<0.05$ compared to vehicle, one-way ANOVA followed by Bonferroni post hoc test.

\section{Figure 2. Post-retrieval treatment with Ro 65-6570 inhibits contextual fear memory}

reconsolidation. (A) Schematic representation of the procedure. CFC, contextual fear conditioning; Ro65, Ro 65-6570. (B) The percentage of time spent freezing during exposure to the conditioning context is significantly reduced in mice treated with $0.1 \mathrm{mg} / \mathrm{kg}$ of NMDA antagonist (MK-801) or $1 \mathrm{mg} / \mathrm{kg}$ of NOP agonist immediately after memory retrieval. Vehicle (n=8), MK-801 0.1 mg/kg (n=8), and Ro 65-6570 $1 \mathrm{mg} / \mathrm{kg}(\mathrm{n}=8)$. (C) Memory retention is not affected if the memory retrieval session is omitted. Vehicle (n=8) and Ro 65-6570 $1 \mathrm{mg} / \mathrm{kg}$ (n=8). (D) A lower dose of $0.1 \mathrm{mg} / \mathrm{kg}$ of Ro 65-6570 is ineffective. Vehicle (n=8), Ro 65$65700.1 \mathrm{mg} / \mathrm{kg}(\mathrm{n}=8)$, and Ro 65-6570 $1 \mathrm{mg} / \mathrm{kg}(\mathrm{n}=8)$. (E) Mice treated with $1 \mathrm{mg} / \mathrm{kg}$ of Ro 65-6570 after memory retrieval still show reduced freezing when tested again 7 days after the first memory assessment. Vehicle $(\mathrm{n}=8)$, Ro $65-65701 \mathrm{mg} / \mathrm{kg}(\mathrm{n}=8)$. Bars represent mean \pm SEM. *, $\mathrm{p}<0.05 ; * *, \mathrm{p}<0.01$ compared to vehicle, two- (B) or one-way (D) ANOVA followed by Bonferroni post hoc test, or unpaired Student t-test (E). 
Figure 3. Post-retrieval treatment with other NOP agonists inhibits contextual fear memory reconsolidation. (A) Schematic representation of the procedure. CFC, contextual fear conditioning. (B) The percentage of time spent freezing during exposure to the conditioning context is significantly reduced in mice treated with N/OFQ i.c.v. immediately after memory retrieval. Vehicle ( $n=9)$, N/OFQ 1 nmole $(n=9)$, and N/OFQ 3 nmoles $(n=9)$. (C) The percentage of time spent freezing during exposure to the conditioning context is significantly reduced in mice treated with the NOP agonist AT-403 i.p. immediately after memory retrieval. Vehicle ( $\mathrm{n}=8)$, AT-403 $0.03 \mathrm{mg} / \mathrm{kg}(\mathrm{n}=9)$, and AT-403 $0.1 \mathrm{mg} / \mathrm{kg}(\mathrm{n}=8)$. Bars represent mean \pm SEM. *, $\mathrm{p}<0.05$ compared to vehicle, one-way ANOVA followed by Bonferroni post hoc test.

Figure 4. Pre-treatment with Ro 65-6570 does not interfere with contextual fear memory retrieval. (A) Schematic representation of the procedure. CFC, contextual fear conditioning; Ro65, Ro 65-6570. (B) The percentage of time spent freezing during the memory retrieval session is similar in mice pre-treated with vehicle or $1 \mathrm{mg} / \mathrm{kg}$ of NOP agonist. Mice pretreated with Ro 65-6570 show a non-significant decrease in memory retention when tested 24h later. Vehicle $(\mathrm{n}=10)$, Ro 65-6570 $1 \mathrm{mg} / \mathrm{kg}(\mathrm{n}=10)$. Bars represent mean \pm SEM.

Figure 5. Post-retrieval treatment with Ro 65-6570 inhibits neuronal activity in subregions of the hippocampus and the amygdala. (A) Left panel: representative images of cFos staining in the dorsal hippocampus. Scale bar $=50 \mu \mathrm{m}$. Examples of positive cells are indicated by arrowheads. Right panel: corresponding quantification of c-Fos positive nuclei. (B) Quantification of c-Fos positive nuclei in the ventral hippocampus and the amygdala. Vehicle (white, $\mathrm{n}=5$ ), Ro 65-6570 $1 \mathrm{mg} / \mathrm{kg}$ (black, $\mathrm{n}=5$ ). Bars represent mean \pm SEM of c-Fos positive nuclei per $\mathrm{mm}^{2}{ }^{*}, \mathrm{p}<0.05$ compared to vehicle, Student t-test. 
Figure 6. Post-retrieval treatment with NOP agonists does not inhibit cue-dependent fear memory reconsolidation. (A) Schematic representation of the procedure. FC, fear conditioning; Ro65, Ro 65-6570. (B) The percentage of time spent freezing during exposure to the CS during the test session is similar in mice treated with vehicle or NOP agonists immediately after memory retrieval. Vehicle (n=8), Ro 65-6570 $1 \mathrm{mg} / \mathrm{kg}(\mathrm{n}=9)$, AT-403 0.1 $\mathrm{mg} / \mathrm{kg}(\mathrm{n}=8)$. 


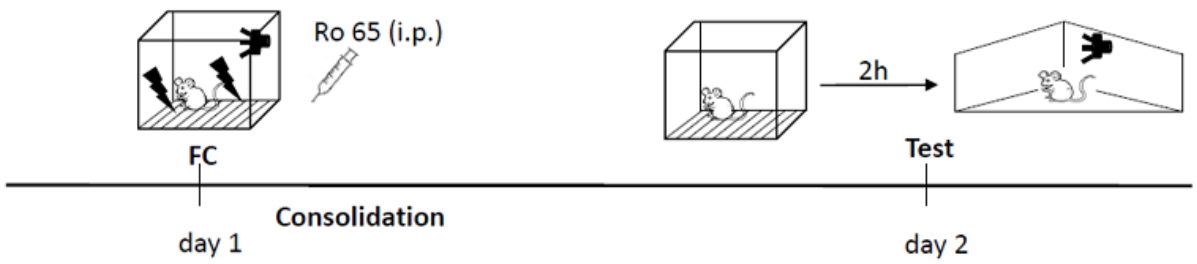

B

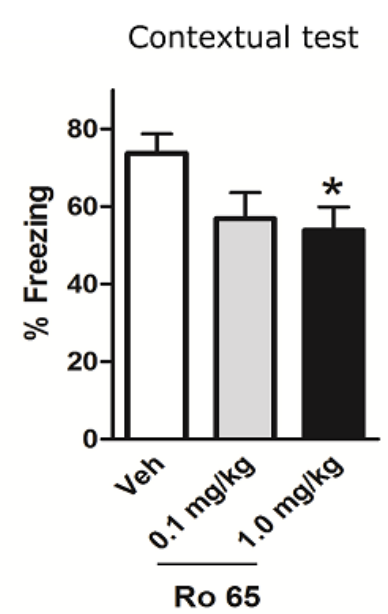

C

Auditory test

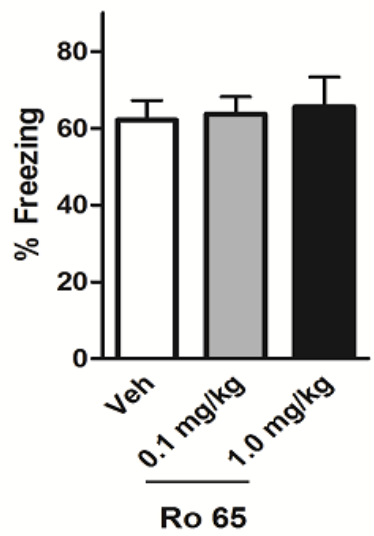

Figure 1 
A

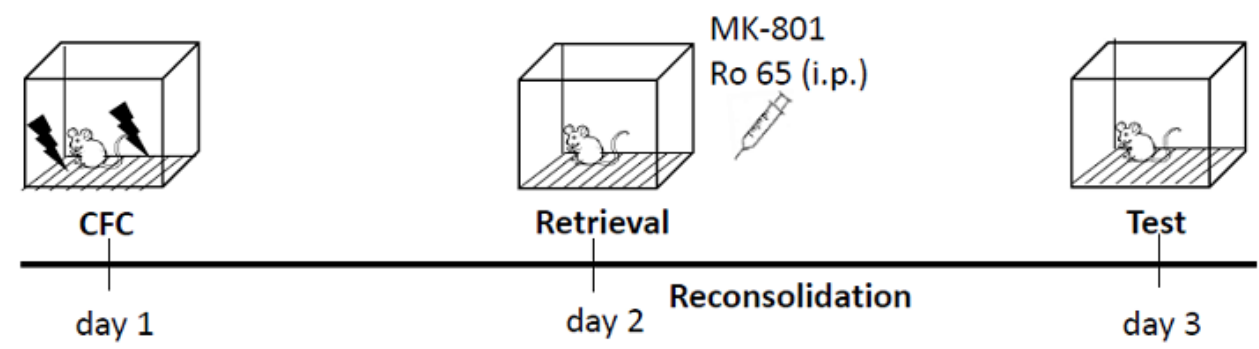

B

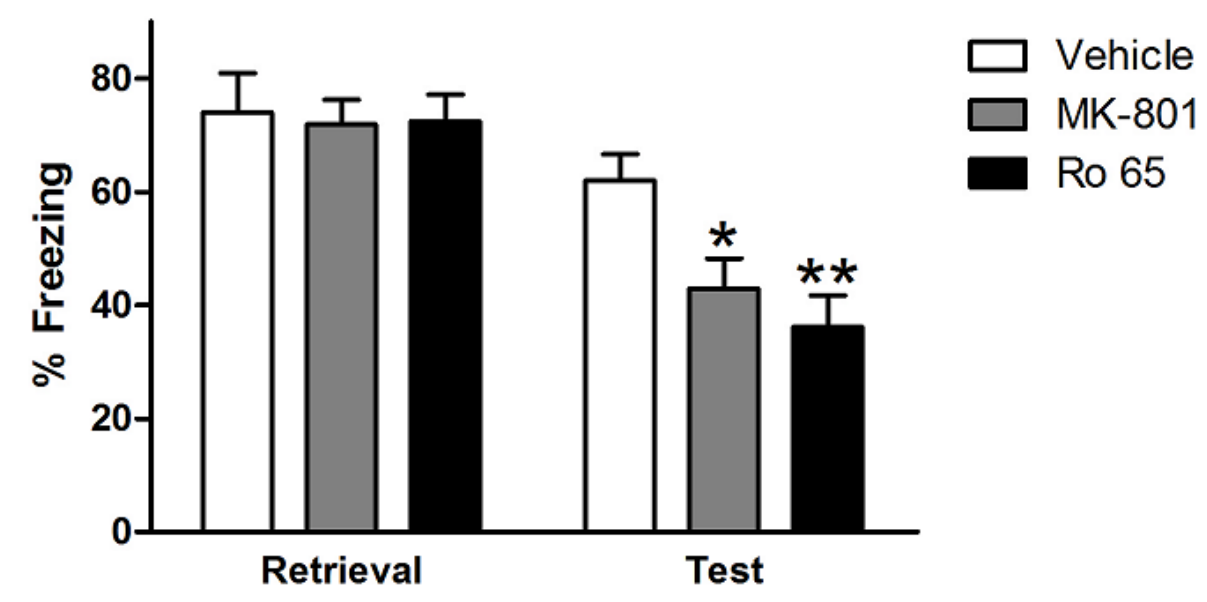

C

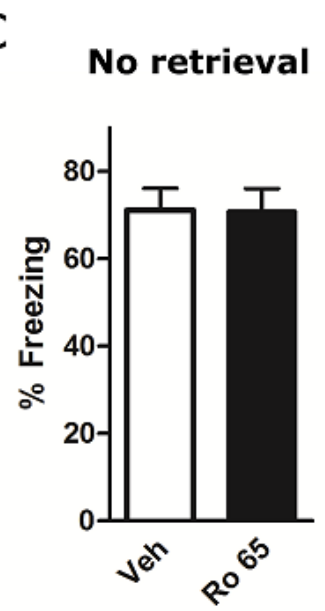

D

E
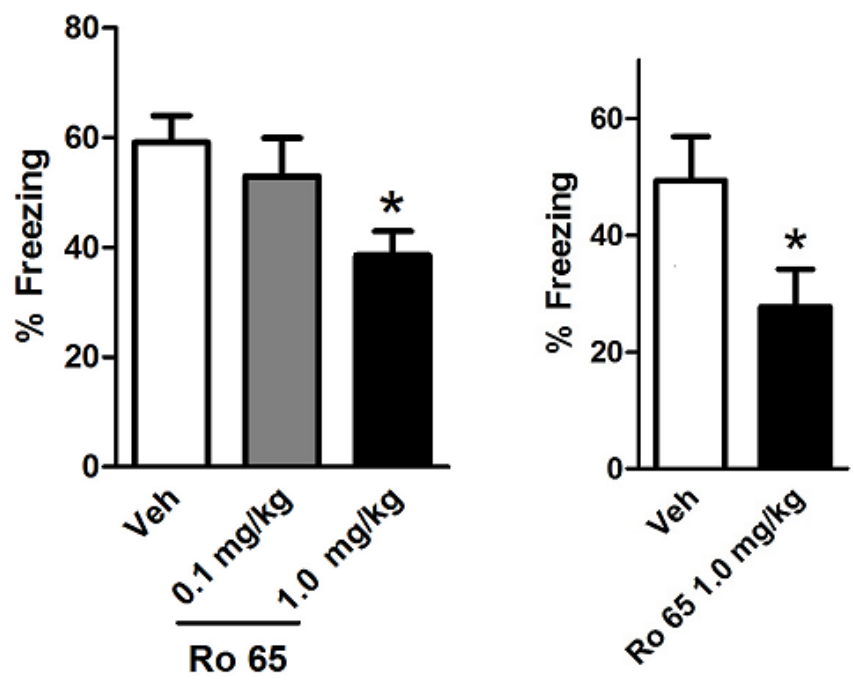

Figure 2 
A
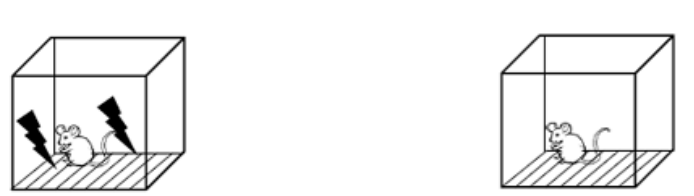

AT-403 (i.p.)

Nociceptin (i.c.v.)

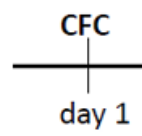

Retrieval
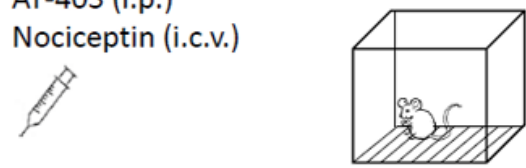

Test

day 1

day 2

Reconsolidation

Test

day 3

B

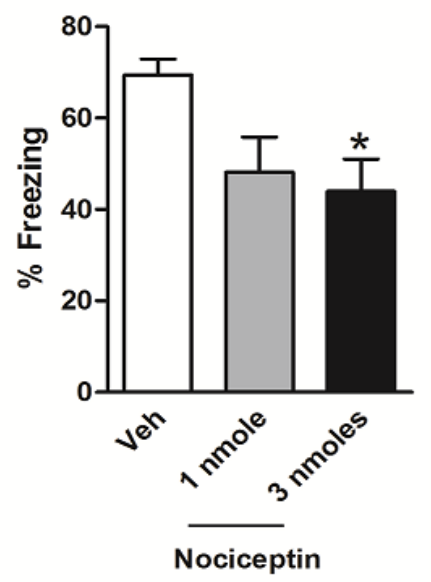

C

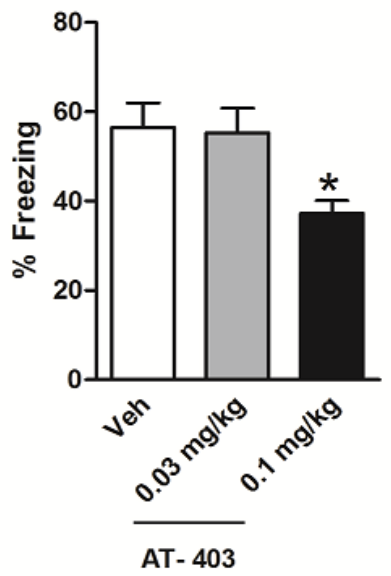

Figure 3 
A

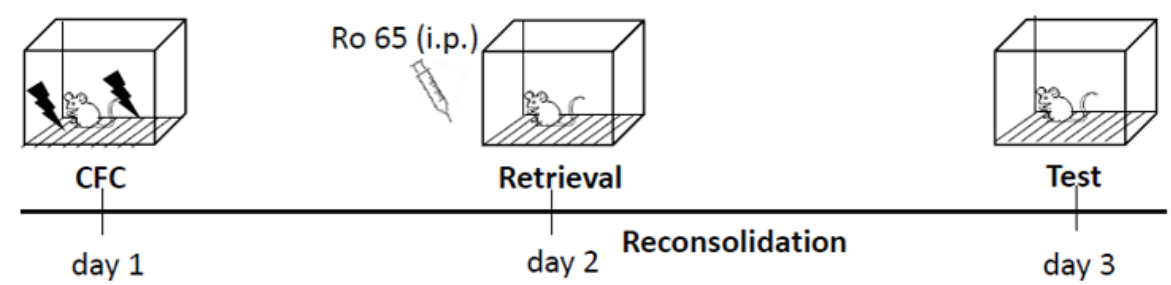

B

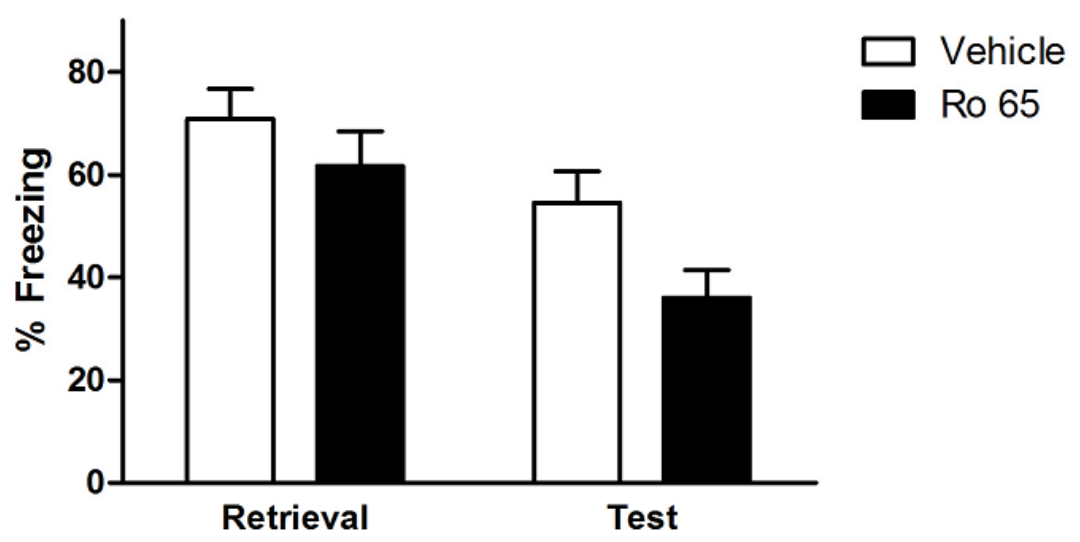

Figure 4 
A

vehicle

Ro 65-6570

dDG
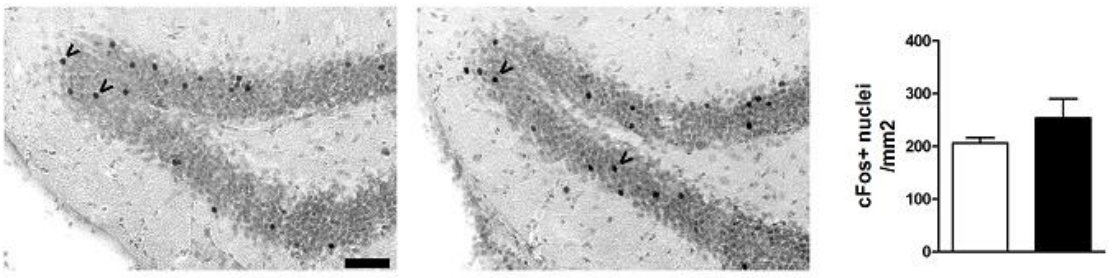

dCA3
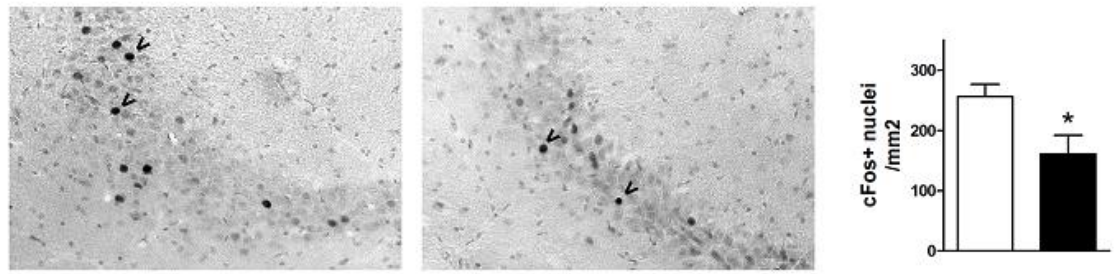

dCA1
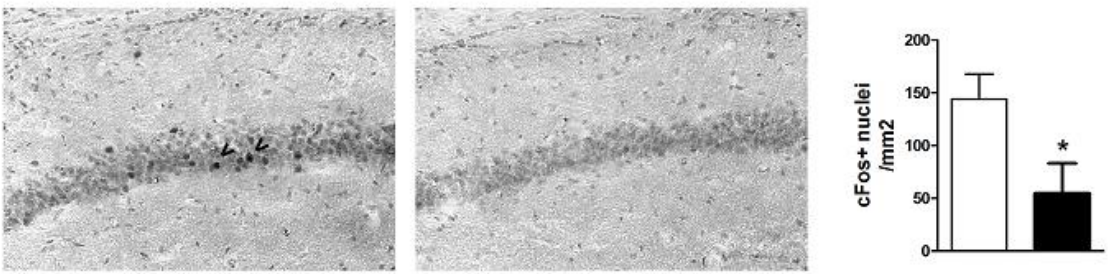

B

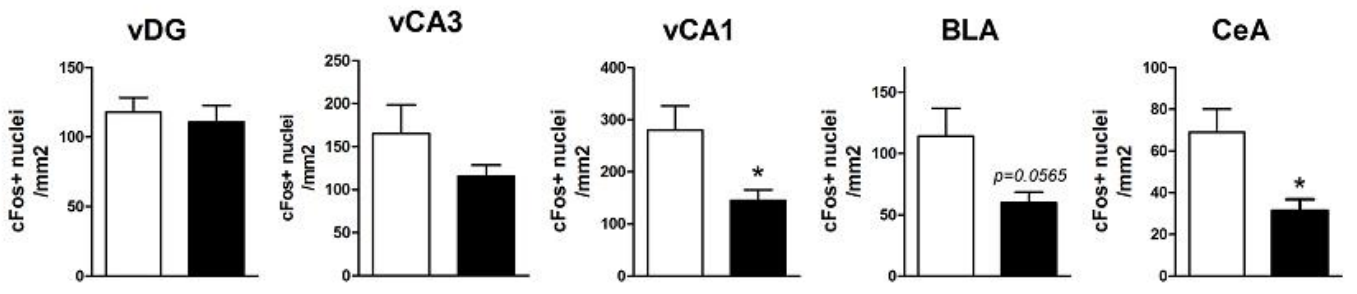

Figure 5 
A

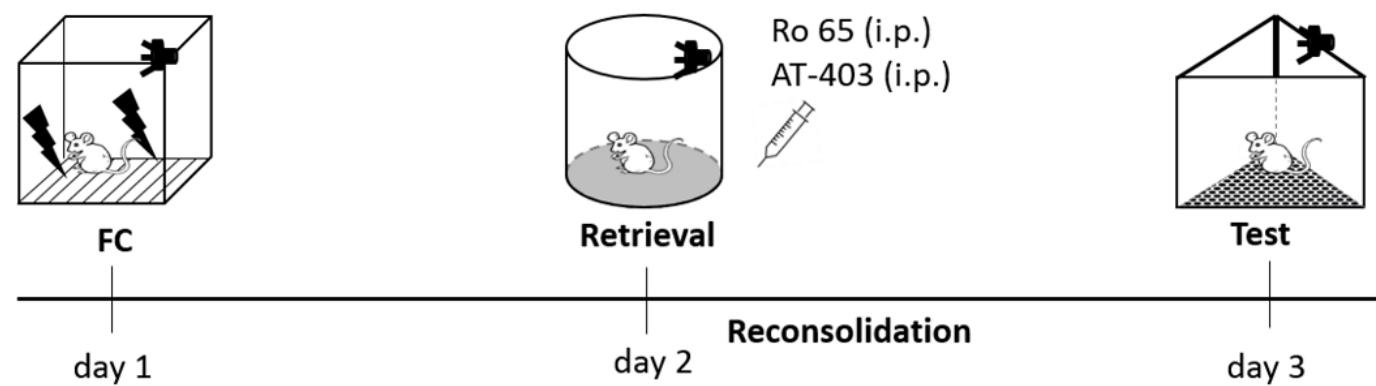

B

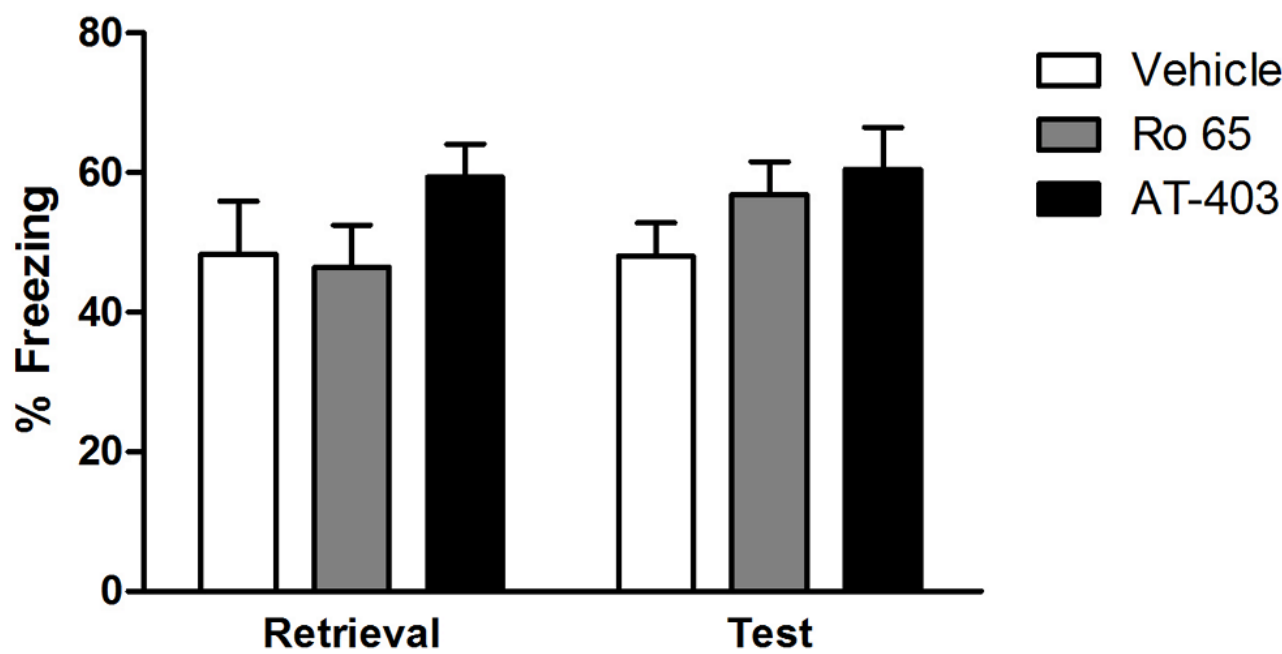

Figure 6 

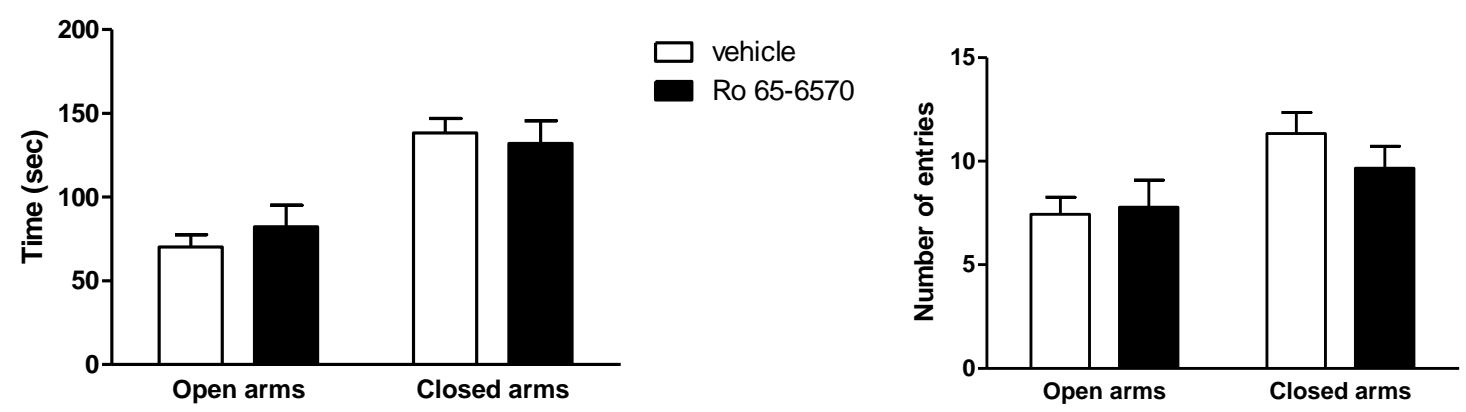

Supplementary Figure 1. Lack of effect of Ro 65-6570 administration in the elevated plus-maze $24 \mathrm{~h}$ after treatment. There is no difference in the time spent in closed and open arms (left) (unpaired t tests, $\mathrm{p}=0.438$ for open arms, $\mathrm{p}=0.701$ for closed arms) nor in the number of entries in each arm (right) between vehicle and Ro 65-6570 treated mice (unpaired $\mathrm{t}$ tests, $\mathrm{p}=0.831$ for open arms, $\mathrm{p}=0.270$ for closed arms). $\mathrm{n}=9$ per group.

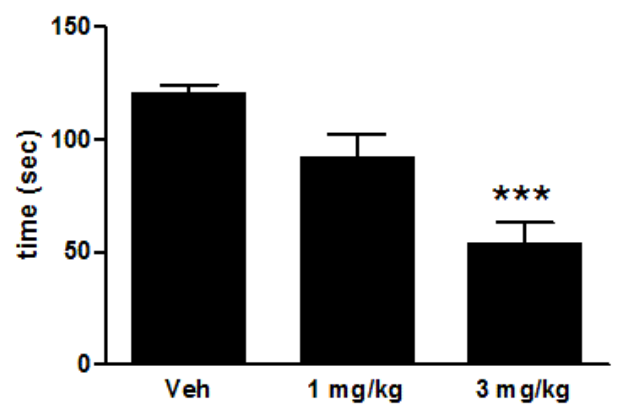

Supplementary Figure 2. A high dose of Ro 65-6570 affects motor coordination.

Treatment with $3 \mathrm{mg} / \mathrm{kg}$ of Ro 65-6570, but not $1 \mathrm{mg} / \mathrm{kg}$, significantly reduces the time spent on the rotarod compared to vehicle-treated mice. ***, $\mathrm{p}<0.001$ compared to vehicle, one-way ANOVA followed by Bonferroni post hoc test $\left(\mathrm{F}_{2,18}=15.35, \mathrm{p}=0.0001\right) . \mathrm{n}=7$ per group. 


\section{Highlights}

- Systemic injection of NOP agonists inhibits contextual fear memory reconsolidation

- NOP agonists inhibit reconsolidation as efficiently as an NMDA receptor antagonist

- NOP agonists reduce c-Fos expression in the hippocampus following memory retrieval

- NOP receptors could be targeted to attenuate hippocampus-dependent memories 